\title{
A new species of solitary Entoprocta (Loxosomatidae) from the Laptev Sea with notes on entoproct epibionts of polychaetes
}

\begin{abstract}
A.O. Borisanova
Faculty of Biology, Moscow State University, Moscow, 119991 Russia. E-mail: borisanovaao@mail.ru

ABSTRACT: A new solitary entoproct species, Loxosomella apicalis sp.n., is described from the Laptev Sea from the depths of 72-90 m. L. apicalis sp.n. is a small species with a body length of 158-323 $\mu \mathrm{m}$ and with an extremely short stalk. Calyx bears 8 tentacles, buds emerge from a frontal budding area. The species is an epibiont of polychaete worms Aglaophamus malmgreni (Nephtyidae). Specimens of L. apicalis sp.n. are attached to the tips of the dorsal cirri or the tips of the gills of the parapodia. The base of the stalk of $L$. apicalis sp.n. grasps tightly the tip of the cirris or the gill. The list of all entoproct species associated with nephtyid polychaetes is given as well as the list of all polychaete families hosted solitary entoprocts, with indication of loxosomatid species.

How to cite this article: Borisanova A.O. 2018. A new species of solitary Entoprocta (Loxosomatidae) from the Laptev Sea with notes on entoproct epibionts of polychaetes // Invert. Zool. Vol.15. No.4. P.373-382. doi: 10.15298/invertzool.15.4.06
\end{abstract}

KEY WORDS: Aglaophamus malmgreni, Kamptozoa, Loxosomatidae, Loxosomella, Arctic, epibiont.

\section{Новый вид одиночных Entoprocta (Loxosomatidae) из моря Лаптевых с замечаниями о внутрипорошицевых - эпибионтах полихет}

\section{А.О. Борисанова}

Биологический факультет Московского государственного университета, Москва, 119991, Россия. E-mail: borisanovaao@mail.ru

РЕЗЮМЕ: Описан новый вид одиночных внутрипорошицевых, Loxosomella apicalis sp.n. из моря Лаптевых, найденный на глубинах 72-90 м. Мелкий вид с длиной тела 158-323 мкм, с очень короткой ножкой. Чашечка несет 8 щупалец, почки отходят от фронтальной зоны чашечки. Особи L. apicalis обитают на параподиях многощетинковых червей Aglaophamus malmgreni (Nephtyidae), прикрепляясь к кончикам дорсальных усиков или жабр параподий с помощью основания ножки, которое плотно охватывает апикальную часть усика или жабры. В статье приведен список всех видов Entoprocta, обитающих на многощетинковых червях семейства Nephtyidae (Phyllodocida), и перечислены все семейства полихет, являющиеся хозяевами для одиночных внутрипорошицевых, с указанием обитающих на них видов Entoprocta. Как цитировать эту статью: Borisanova A.O. 2018. A new species of solitary Entoprocta (Loxosomatidae) from the Laptev Sea with notes on entoproct epibionts of polychaetes // Invert. Zool. Vol.15. No.4. P.373-382. doi: 10.15298/invertzool.15.4.06 
КЛЮЧЕВЫЕ СЛОВА: Aglaophamus malmgreni, Kamptozoa, Loxosomatidae, Loxosomella, Арктика, эпибионты.

\section{Introduction}

Entoprocta (Kamptozoa) is a small phylum, which includes about 180 species of miniature, mostly marine, colonial and solitary animals. Fauna of Entoprocta of the World Ocean remains poorly investigated. In the seas of Russia Entoprocta is one of the less studied groups of invertebrate animals. At present only about 30 species were described from the seas of Russia (Nilus, 1909; Derjugin, 1928; Kluge, 1946; Krylova, 1986; Bagrov, Slyusarev, 2002; Borisanova, Krylova, 2014; Borisanova, 2016a, b; Borisanova, Potanina, 2016; Borisanova et al., 2018). Most of the described species are known from the White Sea. The information on the fauna of entorpocts in other seas is extremely limited. But the studies of the last few years have shown that the diversity of Entoprocta in the seas of Russia is richer than it was previously believed. New species have been described, including species from the Kara Sea (Borisanova, 2016a) and the Sea of Okhotsk (Borisanova, Potanina, 2016; Borisanova et al., 2018), where there were no records of Entoprocta before. In this study a new species of solitary Entoprocta from the Laptev Sea is described, where only two entoproct species were previously known, solitary Loxosoma cingulata Kluge, 1946 and colonial Barentsia discreta (Busk, 1886)(Kluge, 1946). The new species was found living on the polychaete Aglaophamus malmgreni (Théel, 1879) (Nephtyidae), so a list of all known Entoprocta species associated with polychaetes of the Nephtyidae family (Phyllodocida) is given.

\section{Materials and Methods}

The material was collected in the Laptev Sea during the 63-rd cruise of RV Akademik Mstislav Keldysh in September-October 2015. Specimens of Loxosomella apicalis sp.n. were found on the tips of the gills and dorsal cirri of parapodia of Aglaophamus malmgreni (Polychaeta: Nephtyidae) collected at two stations (Fig. 1).
The material was fixed in $4 \%$ formalin, and then transferred to $96 \%$ alcohol for storage.

Holotype and paratypes were imaged and drawn using Leica DM2500 microscope. The body parameters were measured from photographs using the ImajeJ software package.

The type material is deposited in the Zoological Museum of Moscow State University (ZMMU), Moscow.

\section{Description}

Family Loxosomatidae Hincks, 1880

Genus Loxosomella Mortensen, 1911

Loxosomella apicalis sp.n.

Fig. 2, 3.

Type material: ZMMU Uk-25 (holotype); ZMMU Uk-26 (3 paratypes)

Type locality: Laptev Sea, station 5228 (77.6547 $\left.\mathrm{N}, 130.4743^{\circ} \mathrm{E}\right), 90 \mathrm{~m}, 14.09 .2015$, on the polychaete Aglaophamus malmgreni.

Additional material: ZMMU Uk-27 (5 specimens). Laptev Sea, station "seep" (76.7715 ${ }^{\circ} \mathrm{N}$, $\left.125.8418^{\circ} \mathrm{E}\right), 72 \mathrm{~m}, 16.09 .2015$; on the polychaete Aglaophamus malmgreni.

ETYMOLOGY: The species' name "apicalis" means "apical" in Latin and refers to localization of specimens on the tips of gills and cirri.

DIAGNOSIS:

Small species with total body length from 158 to $323 \mu \mathrm{m}$ (length of holotype $208 \mathrm{im}$ ), average body length $235 \mu \mathrm{m}$ (Table 1). Calyx slightly flattened laterally, with 8 tentacles, directed distally in contracted state. Lateral sensory organs absent. Stomach roundish. Stalk very short, from 26 to $62 \mu \mathrm{m}$, average length 36 $\mu \mathrm{m}$. Foot absent in adults. Base of stalk tightly grasps apex of notopodial cirris or gill, so that specimen of $L$. apicalis sp.n. looks like cap on tip. Specimens of L. apicalis sp.n. can be easily detached from tips of cirri or gills without damaging tissues of host or epibiont, so it can be assumed that fixation on host's body provided only by musculature of stalk, without using secretion of attachment glands. 


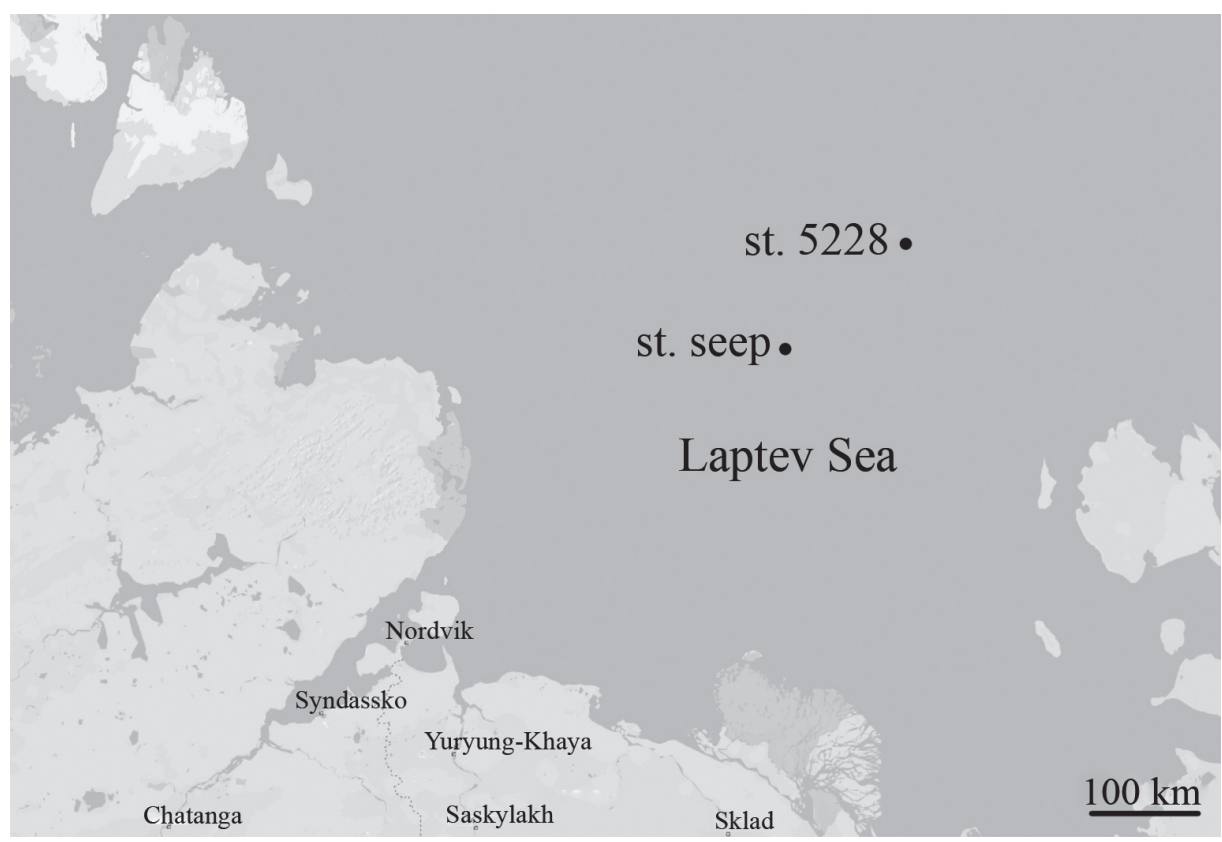

Fig. 1. Map of the sampling sites.

Рис. 1. Карта точек сбора материала.
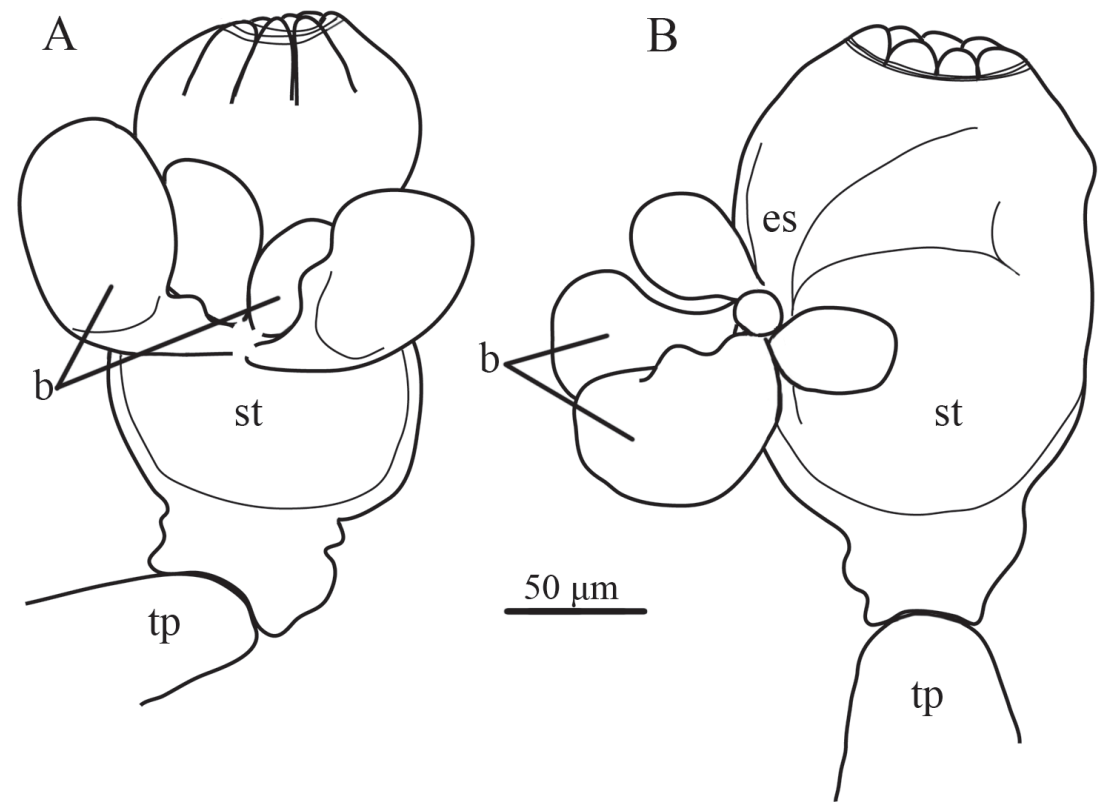

Fig. 2. Loxosomella apicalis sp.n., drawing of holotype. A - frontal view; B - lateral view. Abbreviations: $\mathrm{b}$ - bud; es - esophagus; st - stomach; tp - tip of the dorsal cirri of notopodia.

Рис. 2. Loxosomella apicalis sp.n., рисунок голотипа. А - фронтальный вид; В - латеральный вид. Обозначения: $\mathrm{b}$ - почка; es — пищевод; st — желудок; tp — кончик дорсального усика нотоподии. 

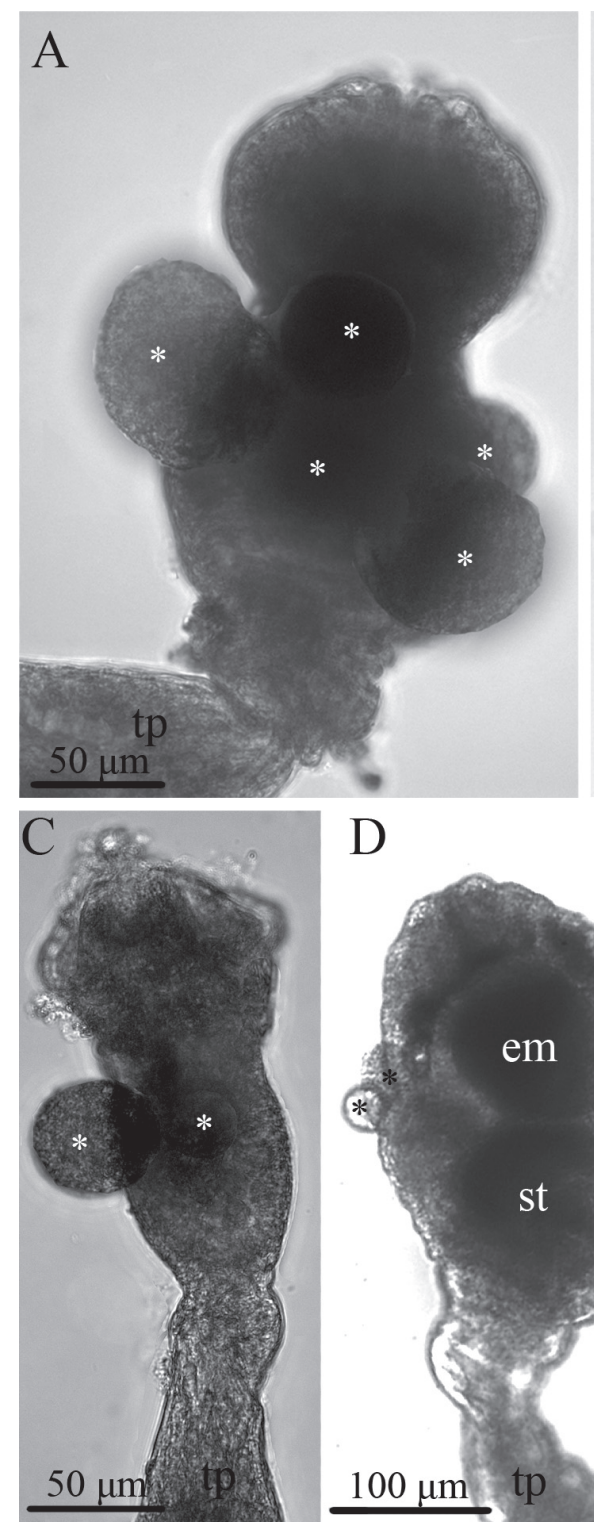

$\mathrm{D}$

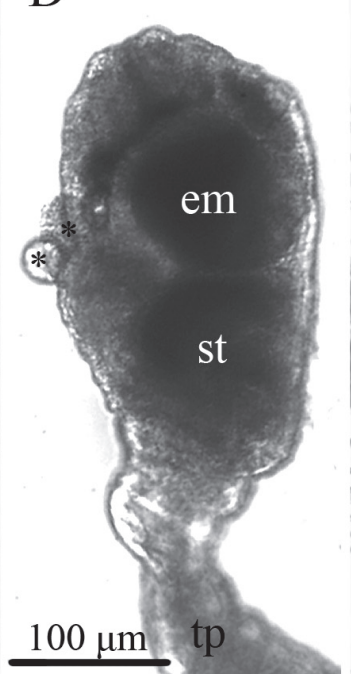

B

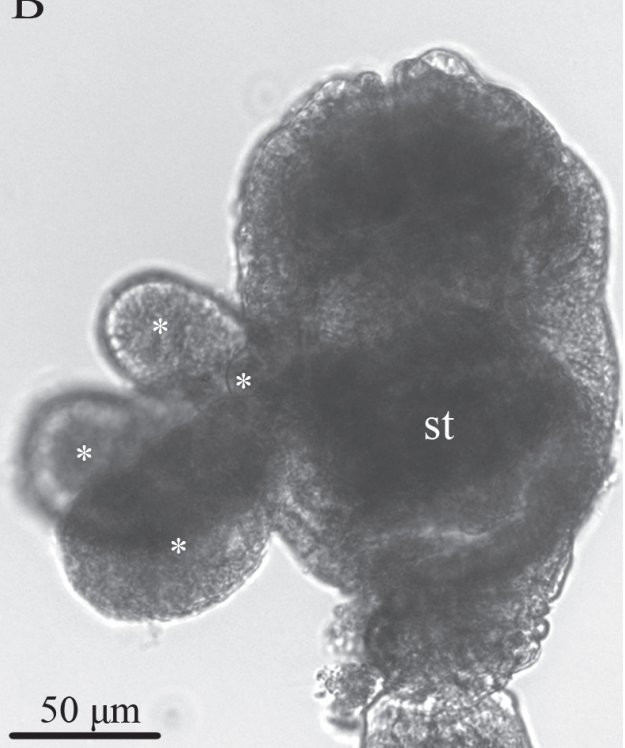

$\mathrm{E}$

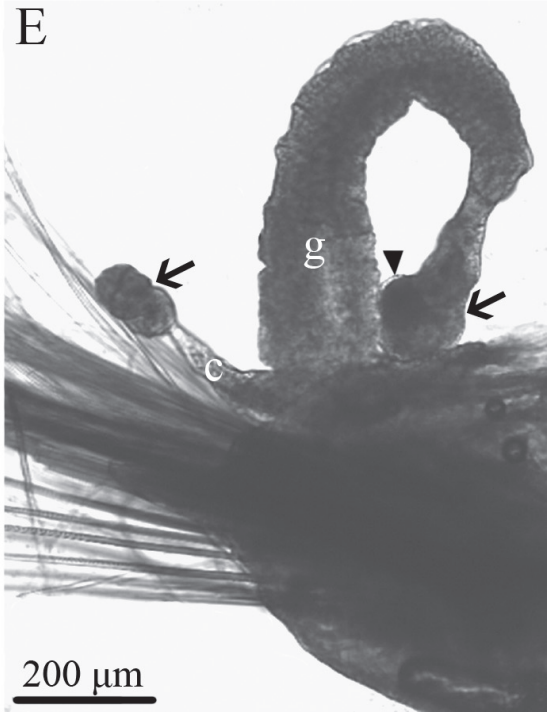

Fig. 3. Specimens of Loxosomella apicalis sp.n., light microscopy. A - holotype, frontal view; B holotype, lateral view; C - paratype, latero-frontal view; D - specimen with developing larvae in the brood chamber; $\mathrm{E}$ - part of parapodia with specimens on the tip of the dorsal cirrus and on the tip of the gill (arrows indicate the location of specimens of L. apicalis sp.n., arrowhead indicates embryo in the brood chamber). Abbreviations: $\mathrm{c}$ - dorsal cirri of notopodia; $\mathrm{em}$ - developing embryo; $\mathrm{g}$ - notopodial gill; st — stomach; tp - tip of the dorsal cirri of notopodia. Asterisks indicate buds.

Рис. 3. Особи Loxosomella apicalis sp.n., микрофотографии. А - голотип фронтально; В — голотип латерально; C - паратип латеро-фронтально; D - особь с развивающейся личинкой в выводковой камере; E - участок параподии с двумя особями - на верхушке дорсального усика и жабры (стрелки указывают на место расположения особей Loxosomella apicalis, наконечник стрелки указывает на выводковую камеру с развивающимся эмбрионом).

Обозначения: c - дорсальный усик нотоподии; $\mathrm{em}$ - развивающаяся личинка; $\mathrm{g}$ - жабра нотоподии; $\mathrm{st}$ желудок; tp - верхушка дорсального усика нотоподии. Звездочками отмечены почки. 
Table 1. Measurements of holotype (*), three paratypes (**) and five specimens (5-9) of Loxosomella apicalis sp.n. from another sampling site $(\mu \mathrm{m})$.

Таблица 1. Loxosomella apicalis sp.n. Размеры тела и число почек голотипа (*), трех паратипов $(* *)$ и пяти особей (5-9) из другой точки сбора (мкм).

\begin{tabular}{|l|c|c|c|c|c|c|c|c|c|}
\hline Specimen & $1^{*}$ & $2^{* *}$ & $3^{* *}$ & $4 * *$ & 5 & 6 & 7 & 8 & 9 \\
\hline Total length & 208 & 158 & 187 & 226 & 216 & 223 & 267 & 312 & 323 \\
\hline Calyx length & 172 & 126 & 149 & 200 & 189 & 185 & 230 & 283 & 261 \\
\hline $\begin{array}{l}\text { Calyx width } \\
\text { in lateral } \\
\text { view }\end{array}$ & 116 & 89 & 78 & 149 & 125 & 103 & 134 & 203 & 144 \\
\hline $\begin{array}{l}\text { Calyx width } \\
\text { in frontal } \\
\text { view }\end{array}$ & 99 & 73 & 68 & - & 109 & 84 & 139 & 159 & 152 \\
\hline Stalk length & 36 & 32 & 38 & 26 & 27 & 38 & 37 & 29 & 62 \\
\hline Stalk width & 57 & 39 & 40 & 72 & 60 & 45 & 62 & 105 & 65 \\
\hline $\begin{array}{l}\text { Amount of } \\
\text { buds }\end{array}$ & 5 & 2 & 2 & 6 & 5 & 3 & 1 & 0 & 3 \\
\hline
\end{tabular}

Reproduction: Frontal budding area with 16 buds. Large buds with well-developed foot. Some specimens with prominent ovaries with several large oocytes. Some specimens with embryos developing in lateral brood chambers (Fig. 3D). Specimens with brood chambers have large roundish protrusions on each side of calyx (Fig. 3E, arrowhead). Brood chamber can be present only on one side of calyx, or two chambers can be located symmetrically on both sides. One embryo develops in each chamber.

Ecology: large number of entoproct specimens may occur on one host, so that they attached to tips of almost all dorsal cirri. Localization on tips of gills is less common. Two specimens of L. apicalis sp.n. can be present simultaneously on same parapodium: one on cirris, and one on gill (Fig. 3E). L. apicalis sp.n. occurs exclusively on tips of cirri and gills, and never were found on lateral surfaces of these organs or on any other parts of parapodia.

DIFFERENTIAL DIAGNOSIS:

Loxosomella apicalis sp.n. is the second solitary entoproct species described from the Laptev Sea. The first species was Loxosoma cingulata Kluge, 1946. Although this species was originally described in the genus Loxoso$m a$, the description is insufficient to ascertain its generic affinities, so Nielsen (1996) assumed its probable belonging to the genus Loxosomella. Considering this supposition the comparison between $L$. apicalis sp.n. and L. cingulata is reasonable. L. cingulata differs from $L$. apicalis sp.n. by larger body length ( $361 \mu \mathrm{m}$ in average) and larger stalk (up to $102 \mu \mathrm{m}, 81 \mu \mathrm{m}$ in average), by number of tentacles ( $8-10)$ and by the presence of lateral wings with gland cells on the calyx. These two species also have different host animals, L. cingulata is an epibiont of bryozoan Rhamphostomella costata Lorenz, 1886, while $L$. apicalis sp.n. is associated with nephtyid polychaete Aglaophamus malmgreni.

Five species of Loxosomatidae besides $L$. apicalis sp.n. are epibionts of polychaetes from the family Nephtyidae (Table 2). Four species belong to genus Loxosomella. Loxosomella scaura Nielsen, 1964 differs from L. apicalis sp.n. by a larger body size (up to $900 \mu \mathrm{m}$ ), number of tentacles (10-14 tentacles), relatively long stalk, and the way of the attachment to the substrate. Loxosomella brachystipes Franzén, 1973 has larger body size (up to $500 \mu \mathrm{m}$ ), 6 to 12 tentacles, and two lateral budding areas on the calyx. Loxosomella varians Nielsen, 1964 is similar to L. apicalis sp.n. by morphology, although the specimens of $L$. varians can reach 


\begin{tabular}{|c|c|c|c|c|c|c|}
\hline 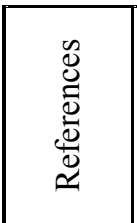 & 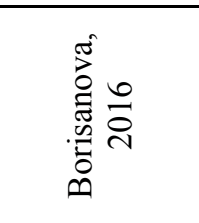 & 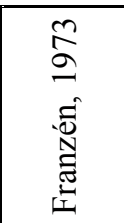 & 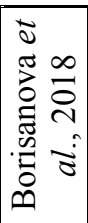 & 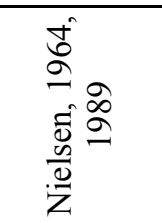 & 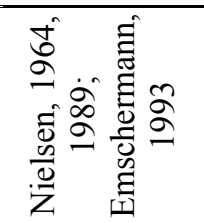 & 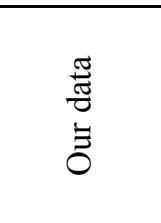 \\
\hline 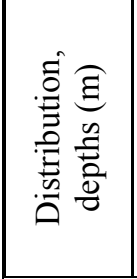 & 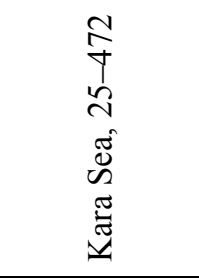 & 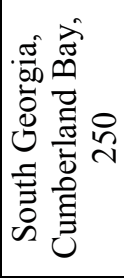 & 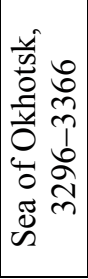 & 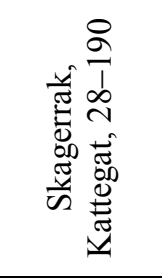 & 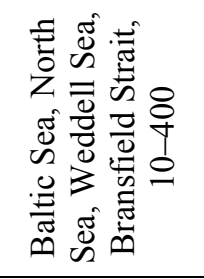 & 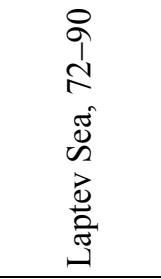 \\
\hline 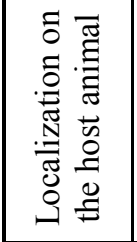 & 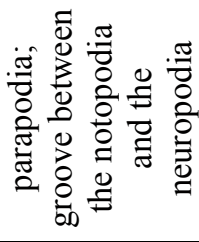 & 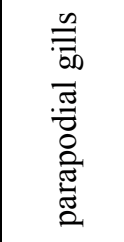 & 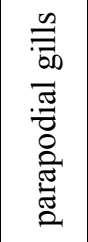 & 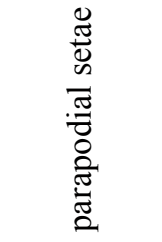 & 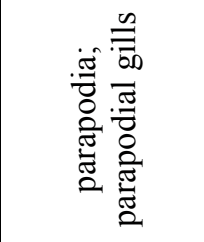 & 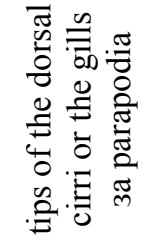 \\
\hline $\begin{array}{l}0 \\
0 \\
0 \\
0 \\
0 \\
0 \\
0 \\
0 \\
0\end{array}$ & 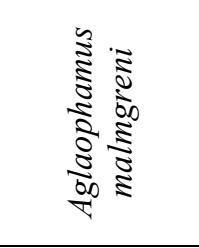 & 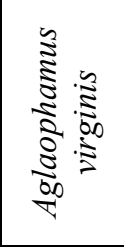 & 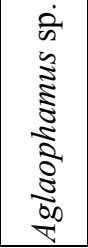 & 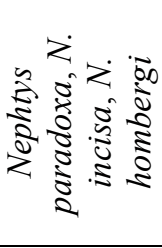 & 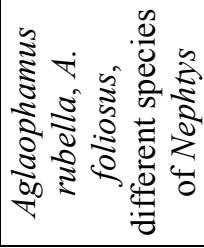 & 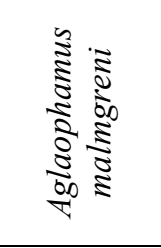 \\
\hline 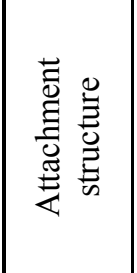 & 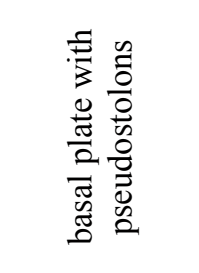 & 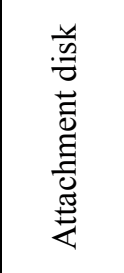 & 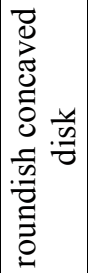 & 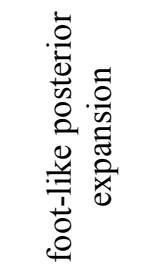 & 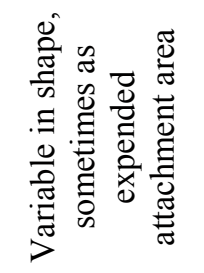 & 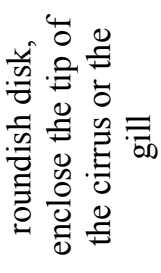 \\
\hline 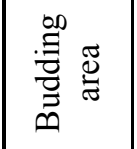 & 莺 & 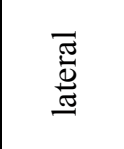 & 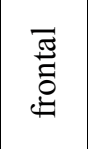 & 苞 & 吾 & 莺 \\
\hline 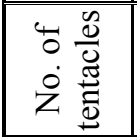 & $\frac{0}{1}$ & $\frac{1}{b}$ & $\infty$ & $\stackrel{ \pm}{ \pm}$ & $\infty$ & $\infty$ \\
\hline 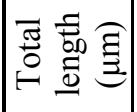 & in & $\stackrel{\odot}{\sim}$ & 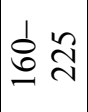 & $\begin{array}{l}\stackrel{8}{\swarrow} \\
\equiv\end{array}$ & 욜 & 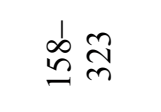 \\
\hline 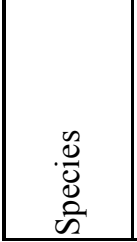 & 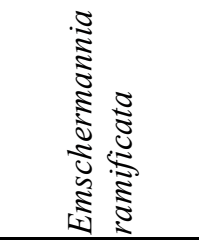 & 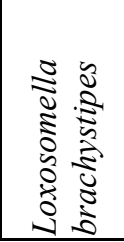 & 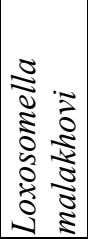 & 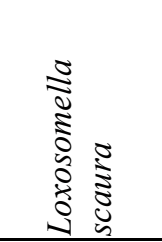 & 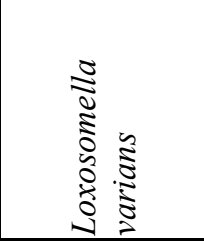 & 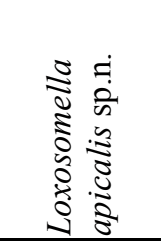 \\
\hline
\end{tabular}


length of $750 \mu \mathrm{m}$ and have a variable structure of the attachment organs. Morphology of Loxosomella malakhovi Borisanova, Chernyshev et Ekimova, 2017 is almost identical to morphology of L. apicalis sp.n. Both species are small, with 8 tentacles, frontal budding area and short stalk, although in L. malakhovi the stalk is slightly longer (in L. malakhovi stalk length varies from 30 to $60 \mu \mathrm{m}$, in average $46 \mu \mathrm{m}$; in $L$. apicalis it varies from 26 to $62 \mu \mathrm{m}$, in average $36 \mathrm{im}$ ). Both species are associated with polychaetes of the genus Aglaophamus Kinberg, 1865 , but location on host's body is different in these two species. All the investigated L. malakhovi specimens were attached to the lateral surfaces of the gills, grasping the soft tissue of the gill with its attachment disk. L. apicalis sp.n. was never found on the surface of the gills, only on the tips of the gills and cirri. The geographical distribution of these species also differs: $L$. apicalis sp.n. lives in the shelf zone of the Laptev Sea, L. malakhovi is a deep-water species from the Sea of Okhotsk, described from the depths of 3296-3366 m.

\section{Discussion}

A unique feature of L. apicalis sp.n., which does not occur in any other described species of Entoprocta, is the location on the host's body. $L$. apicalis sp.n. attaches to the very tips of the gills and dorsal cirri of parapodia, grasping them with the base of the stalk. Other entoproct species can attach to the surface of parapodia as Loxosomella akkeshiensis (Yamada, 1956) or L. aripes Nielsen, 1964 or to parapodial gills, as for example, Loxosomella perezi (Bobin et Prenant, 1953), L. varians to the body surface of the polychaete, as Loxosoma pectinaricola Franzén, 1962, L. rhodinicola Franzén, 1962, Loxosomella fagei Bobin et Prenant, 1953. Loxosomella species living as epibionts of Polynoidae and Aphroditidae polyhaetes, can attach to elytra (L. obesa (Atkins, 1932), L. pseudocompressa Konno, 1977). Some species attach to parapodial chaetae (Loxosomella antis Krylova, 1985, L. scaura). But L. apicalis sp.n. is the only species which attaches to the tips of the gills and cirri.
Polychaeta is one of the main groups of host animals for solitary entoprocts. More than 60 species of Loxosomatidae (42 species of Loxosomella, 24 species of Loxosoma and the only species of Emschermannia, E. ramificata Borisanova, 2016) are associated with polychaetes. Entoprocts can be found in tubes and on the body surface of both sessile and errant polychaetes from 15 families (Table 3). Species from the family Maldanidae are hosts for the largest number of loxosomatids. Twelve species of genus Loxosoma and six species of genus Loxosomella are epibionts of maldanid polychaetes, and most of them attach to the tubes of the host species. Relatively large number of species are also associated with polychaetes from family Terebellidae (one Loxosoma species and nine Loxosomella species), and only three of them are attached to the body surface, other live in tubes of the host animals. In general, most of epibiotic entoproct species are associated with sessile polychaetes (53 species). The host animals apparently provide loxosomatids with a safe environment and with water currents that bring suspended food particles (Nielsen, 1964; Iseto, 2005). Entoprocts, which associated with errant polychaetes, are most frequently attached to the parapodia, and apparently use water currents created by parapodia movement. The epibionts of the sedentary polychaetes obviously use the water current passing through the tubes. Probably, the current, created by sessile worms, is optimal for entoprocts. It is also necessary to take into account the physical opportunity for entoproct larvae to find a host and attach to it. It can be assumed that it is easier for the larva to get inside tubes of the sedentary polychaetes with water currents generated by host than try to attach themselves to the body of the errant worms.

\section{Acknowledgments}

The research was financially supported by the Russian Science Foundation (project no. 1450-00029). Proceeding of the paper is supported by the Russian Science Foundation (project no. 18-14-00082). The author is grateful to the Shirshov Institute of Oceanology, Russian Acad- 


\begin{tabular}{|c|c|c|c|c|c|c|c|c|c|c|c|c|c|c|}
\hline 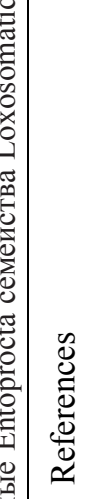 & 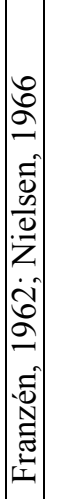 & 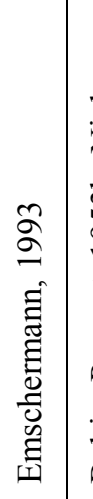 & 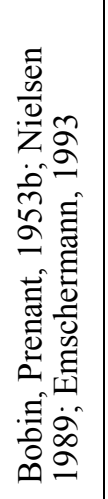 & 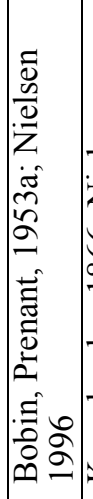 & 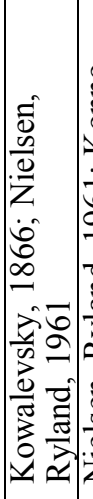 & 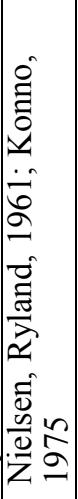 & 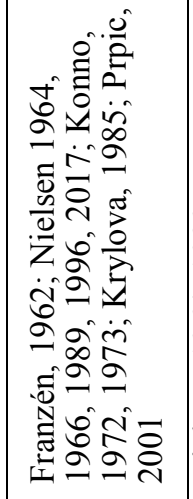 & 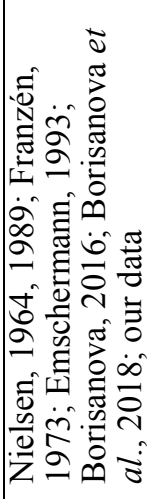 & 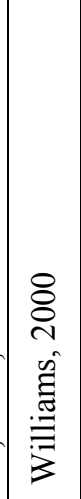 & 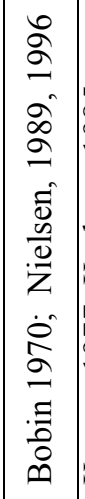 & 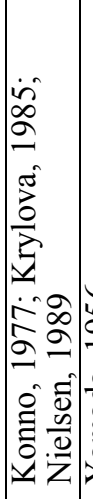 & 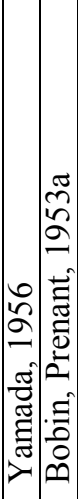 & 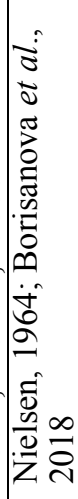 & 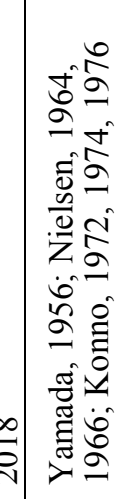 \\
\hline 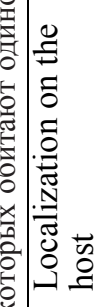 & 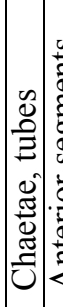 & 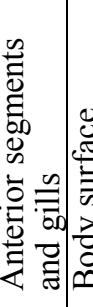 & 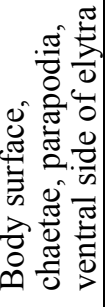 & 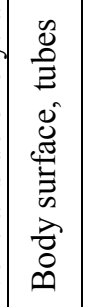 & 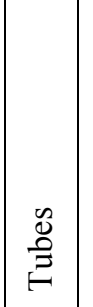 & 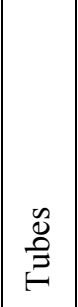 & 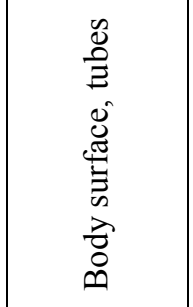 & 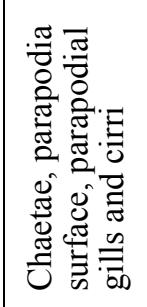 & 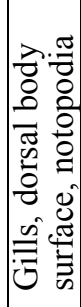 & 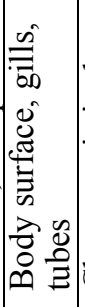 & 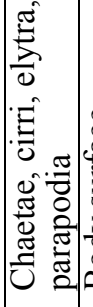 & 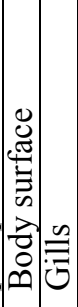 & 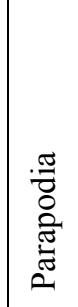 & 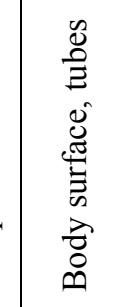 \\
\hline 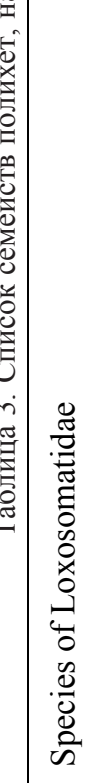 & 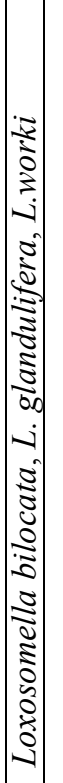 & 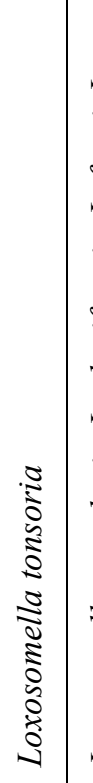 & 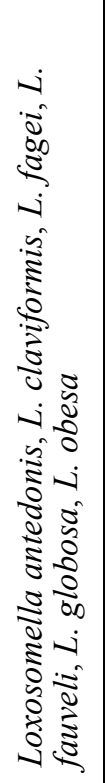 & 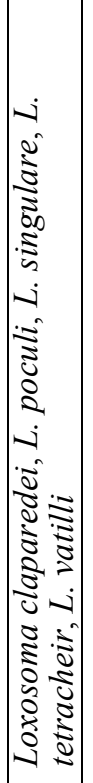 & 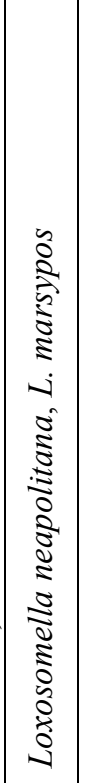 & 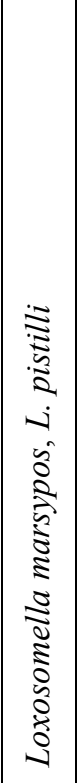 & 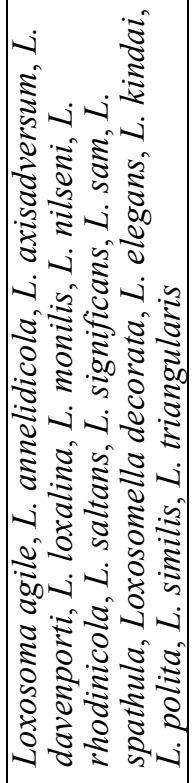 & 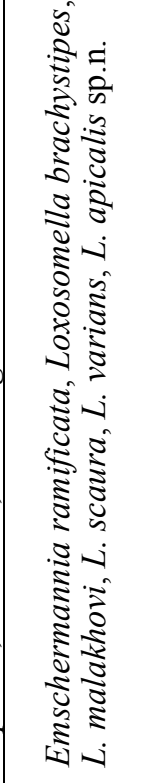 & 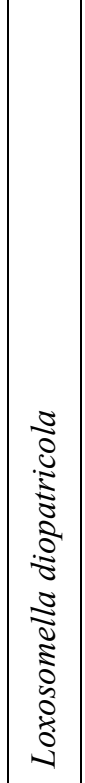 & 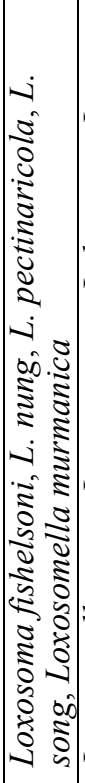 & 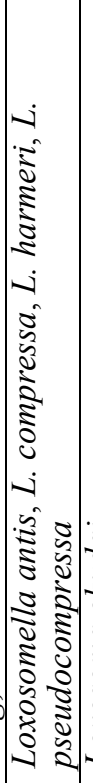 & 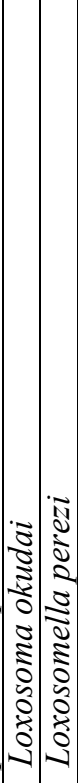 & 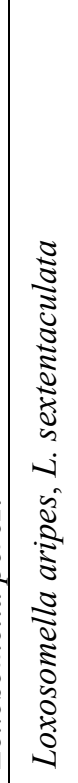 & : \\
\hline 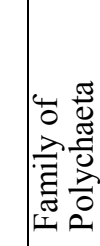 & 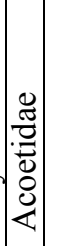 & 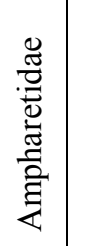 & 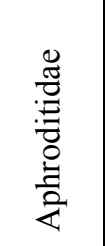 & 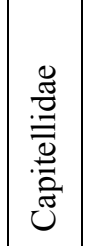 & 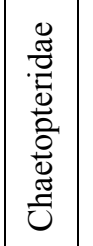 & 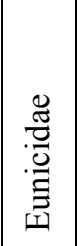 & 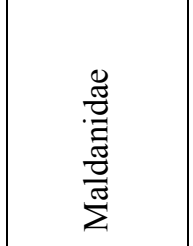 & 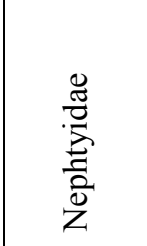 & 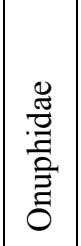 & 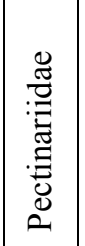 & $\begin{array}{l}\frac{\tilde{J}}{0} \\
.0 \\
0 \\
5 \\
0 \\
0\end{array}$ & 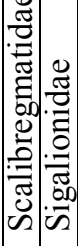 & $\begin{array}{l}\frac{\pi}{0} \\
\frac{\pi}{0} \\
\frac{0}{2} \\
\text { क }\end{array}$ & 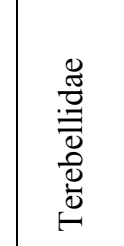 \\
\hline
\end{tabular}


emy of Sciences (IO RAS) for provided material. The author is deeply thankful to Dr. E.M. Krylova (IO RAS) and Dr. N.N. Shunatova (St Petersburg University) for valuable comments on the manuscript.

\section{References}

Bagrov S.V., Slyusarev G.S. 2002. A new species of Loxosomella from the White Sea (Entoprocta: Loxosomatidae) // Zoosystematica Rossica. Vol.10. P.281283.

Bobin G. 1970. Loxosoma fishelsoni n.sp. (Entoprocta: Loxosomaiidae) du Golfe d'Akaba // Israel Journal of Zoology. Vol.19. No.2. P.111-124.

Bobin G., Prenant M. 1953a. Deux Loxosomes nouveaux de Roscoff // Archives de Zoologie Expérimentale et Générale. Vol.91. P.25-35.

Bobin G., Prenant M. 1953b. Sur trois Loxosomes méditerranéens // Bulletin de 1'Institut Océanographique. Vol.1030. P.1-9.

Borisanova A.O. 2016a. Emschermannia ramificata - a new genus and species of solitary entoproct from the Kara Sea, Russia // Zootaxa. Vol.4084. No.1. P.135142.

Borisanova A.O. 2016b. A new species of solitary Entoprocta, Loxosomella angusta sp.n., from the White Sea // Invertebrate Zoology. Vol.13. P.43-50.

Borisanova A.O., Chernyshev A.V., Ekimova I.A. 2018. Deep-sea Entoprocta from the Sea of Okhotsk and the adjacent open Pacific abyssal area: new species and new taxa of host animals // Deep Sea Research. Vol.154. P.87-98.

Borisanova A.O., Krylova E.M. 2014. A new species of Loxosomatidae (Entoprocta, Solitaria) from the White Sea: Loxosomella unicornis sp.nov. // Zootaxa. Vol.3861. No.3. P.290-296.

Borisanova A.O., Potanina D.M. 2016. A new species of Coriella, Coriella chernyshevi n.sp. (Entoprocta, Barentsiidae), with comments on the genera Coriella and Pedicellinopsis // Zootaxa. Vol.4184. No.2. P.376382.

Derjugin K.M. 1928. [The fauna of the White Sea and the conditions for its existence] // K.M. Derjugin (ed.). Issledovaniya morei SSSR Seas. Leningrad. No.7-8. P.1-511 [in Russian].

Emschermann P. 1993. On Antarctic Entoprocta: nematocyst-like organs in a Loxosomatid, adaptive developmental strategies, host specificity and bipolar occurrence of species // Biological Bulletin (Woods Hole). Vol.184. P.153-185.

Franzén A. 1962. Studies on Entoprocta from the west coast of Sweden // Zoologiska Bidrag från Uppsala. Vol.33. P.311-327.

Franzén Å. 1973. Some Antarctic Entoprocta with notes on morphology and taxonomy in the Entoprocta in general // Zoologica Scripta. Vol.2. P.183-195.
Iseto T. 2005. A review of non-commensal loxosomatids: collection, culture, and taxonomy, with new implications to the benefit of commensalism (Entoprocta: Loxosomatidae) // H.I. Moyano, J.M. Cancino, P.N. Wyse Jackson (eds.). Bryozoan studies 2004. London: Taylor and Francis. P.133-140.

Kluge H.A. 1946. [Kamptozoa from the Arctic Ocean] // V.K. Buinitski (ed.). Trudy dreifuyushchei ekspeditsii na ledokolnom parokhode "G. Sedov", 1937-1940 gg. Vol.3. Moscow: Arctic Science Research Institute. P.149-157 [in Russian]

Konno K. 1972. Studies on Japanese Entoprocta. I. On four new species of loxosomatides found at Fukuara, Aomori Prefecture // The Science Reports of the Hirosaki University. Vol.19. P.64-78.

Konno K. 1973. Studies on Japanese Entoprocta II. On a new species of Loxosoma and Loxosomella akkeshiensis (YAMADA) from Fukaura // The Science Reports of the Hirosaki University. Vol.20. P.79-87.

Konno K. 1974. Studies on Japanese Entoprocta III. On Loxosoma cubitus sp.nov. from Fukaura // The Science Reports of the Hirosaki University. Vol.21. P.6770.

Konno K. 1975. Studies on Japanese Entoprocta V. On Loxosomella pistilli sp.nov. found in the tube of Palola siciliensis (Grube) // The Science Reports of the Hirosaki University. Vol.22. P.79-81.

Konno K. 1976. Studies on Japanese Entoprocta VI. Three new loxosomatids found at Fukaura // The Science Reports of the Hirosaki University. Vol.23. P.43-49.

Konno K. 1977. Studies on Japanese Entoprocta VII. On two new species of Loxosomatidae // The Science Reports of the Hirosaki University. Vol.24. P.81-84.

Kovalevsky A.O. 1866. Beiträge zur Anatomie und Entwicklungsgeschichte des Loxosoma neapolitanum sp.n. // Mémoires de l'Academie Impériale des Sciences de St-Pétersbourg. Vol.10. No.2. P.1-10.

Krylova E.M. 1985. [Two new species of the genus Loxosomella (Kamptozoa, Loxosomatidae) from the White Sea] // Zool. Zhurn. Vol.64. P.1262-1264 [in Russian, English summary].

Krylova E.M. 1986. [Entoprocta of the White Sea] // 7th All-Union Colloquium on Fossil and Recent Bryozoa. Abstracts. Moscow. P.59-60 [in Russian].

Nielsen C. 1964. Studies on Danish Entoprocta // Ophelia. Vol.1. P.1-76

Nielsen C. 1966. Some Loxosomatidae (Entoprocta) from the Atlantic coast of the United States // Ophelia. Vol.3. No.1. P. 249-275.

Nielsen C. 1989. Entoprocts: Keys and notes for the identification of the species // Synopses of the British Fauna (New Series). Vol.41. P.1-131.

Nielsen C. 2017. Loxosomella decorata n.sp., a new solitary entoproct from San Juan Island, WA, USA // Zootaxa. Vol. 4238. No.4. P.594-596.

Nielsen C., Ryland J.S. 1961. Three new species of Entoprocta from West Norway // Sarsia. Vol.1. No.1. P.3945.

Nilus G. 1909. [Loxosoma murmanica and Loxosoma brumpti sp.n.] // Trudy Imperatorskogo Sankt-Peter- 
burgskogo Obshchestva Estestvoispytateley. Vol.40. P.157-169 [in Russian]

Prpic N.M. 2001. A new species of Loxosoma from northwestern Finistere, France (Spiralia, Kamptozoa (= Entoprocta), Solitaria, Loxosomatidae) // Spixiana. Vol.24. No.2. P.97-102.

Williams J.B. 2000. Descriptions of two loxosomatids (Entoprocta), with emphasis on a relationship be- tween symbiont attachment structures and cuticle // Canadian Journal of Zoology. Vol.78. P.110-120. Yamada M. 1956. The fauna of Akkeshi Bay XXIV. Entoprocta // Journal of the Faculty of Science, Hokkaido University. Ser.6, Zoology. Vol.12. P.237-243.

Responsible editors A.V. Chernyshev, E.N. Temereva 